UDC 159.9

\title{
LEARNED HELPLESSNESS OF MIGRANTS AT DIFFERENT STAGES OF ADAPTATION: STUDIES REVIEW
}

\section{Ponomareva I.V., Sizova Ya.N.}

Purpose. Successful adaptation of migrants is a global social issue. The article presents a theoretical review of research on problems of learned helplessness while migrants'adaptation.

Methodology. A theoretical review of research on problems of "learned helplessness" and "migrants", cross-references.

Results. The learned helplessness of migrants uprises as a reaction to uncontrolled events and cultural shock. Learned helplessness symptoms aggravation occurs at the initial stage of adaptation and may lead to return to the country of origin.

Practical implications. The motivational, cognitive and emotional deficits of learned helplessness complicate adaptation. The findings theoretically justify the hypothesis about cultural and ethnic determinants of mental health of migrants. The findings are important for social and psychological support of migrants' adaptation and integration, as well as for future research on how migration experience affects values and more distant development processes of migrants in host communities.

Keywords: Learned helplessness; migrants; adaptation.

\section{ВЫУЧЕННАЯ БЕСПОМОЩНОСТЬ МИГРАНТОВ НА РАЗЛИЧНЫХ СТАДИЯХ АДАПТАЦИИ: ОБЗОР ИССЛЕДОВАНИЙ}

\section{Пономарева И.В., Сизова Я.Н.}

Цель. Успешная адаптация мигрантов - это глобальная соцчиальная проблема. В статье представлен теоретический обзор 
исследований проблем выученной беспомощности при адаптащии мигрантов.

Методология. Теоретический обзор исследований по проблемам “выученной беспомощности” и “мигрантов”, перекрестные ссылки.

Результаты. Выученная беспомощность мигрантов возникает как реакция на неконтролируемые события и культурный шок. Обострение симптомов выученной беспомощности происходит на начальном этапе адаптации и может привести к возвращению в страну происхождения.

Область применения. Мотивационный, когнитивный и эмоциональный дефиџит выученной беспомощности затрудняет адаптацию. Полученные результаты теоретически обосновывают гипотезу о культурно-этнических детерминантах психического здоровья мигрантов. Полученные результаты имеют важное значение для социально-психологической поддержки адаптаџии и интеграции мигрантов, а также для будущих исследований влияния миграциионного опыта на иенности и более отдаленные прочессы развития мигрантов в принимающих сообществах.

Ключевые слова: выученная беспомощность; мигранты; адаптащуия.

\section{Introduction}

The global context of the existence of modern society is marked by the damage of the humanitarian world's integrity. First of all, this damage is manifested in mass migration of population. Social and psychological consequences of migration processes appear in two main aspects. On the one hand, within the problems of migrants' integration into the host community, the perception of its culture, laws and regulations, harmonization of relations with the local community. On the other hand, within studying the problems of the host society through the problems of perception of migrants, attitudes to certain cultural and religious groups, willingness to interact with migrant communities. The need to promote adaptation and integration of migrants, to establish constructive interaction between them and the host community has determined the relevance of this study, its social and practical significance. 


\section{Materials and Methods}

A review of studies (Informa PLC, elibrary.ru, Researchgate, PMC) on the learned helplessness of migrants was conducted in 2018 using the keywords "learned helplessness" and "migrants", as well as cross-references. Articles devoted to this problem have been studied in detail for the theoretical analysis of the relevant studies.

\section{Results}

Thus, the problem of migration remains relevant for modern Russia; successful adaptation of migrants, willingness of the host population to interact with them stimulates cultural and professional development, improve communication skills and affect value orientations and attitudes. However, being in a different ethnic, cultural and linguistic environment, one category of migrants effectively orientates in the new situation, shows independence and optimism, whereas the other experiences psychological difficulties, demonstrates passivity, helplessness and indifference, easily becomes despondent and even depressed. Pessimistic expectations and uncontrollable repeated stressful events because of moving to another country are an obstacle to social and psychological adaptation and cause a state of learned helplessness.

The state of learned helplessness results from failure, a traumatic event [7].

The lack of control of migrants in a new cultural environment can stimulate a feeling of helplessness and despair, reduce self-esteem and self-confidence, which leads to a state of helplessness. Failure or lack of control makes them believe that they are unable to do anything to improve their situation [11].

The phenomenon of learned helplessness is associated with motivation breakdown as a result of the subject's experience of uncontrollability of a situation, independence of the result on the efforts applied. Human behavior in a state of learned helplessness is characterized by three deficits: cognitive, motivational and emotional ones. Cognitive deficit involves difficulties to learn that, in a similar situation objectively controlled by the subject, attempts to intervene can be effective. Motivational deficit 
manifests in the absence of attempts to galvanize oneself into action, in reduction of active intervention in the situation, it is characterized by a lack of initiative, perseverance, tenacity in achieving goals. Emotional deficit of learned helplessness is manifested in a depressed mood, a sense of hopelessness, increased anxiety, arising from ineffectiveness of their own actions $[13, \mathrm{p} .4]$.

Thus, the individual in a state of learned helplessness is not confident in his/her own abilities, perceives the situation as uncontrollable, refuses to try to change the existing situation, to influence the results in the future. The subject is unable to be flexible, to realize that each situation is unique and bad experience while dealing with one problem may not be repeated while solving another one. The symptoms of learned helplessness are passivity, sadness, anxiety, hostility, cognitive, motivational and emotional deficits, reduced self-respect, etc. [4].

Some people can experience the state of learned helplessness as a result of the slightest failure, whereas the others due to repeated traumatic events of high intensity. A risk factor of the state of learned helplessness is, according to some researchers, pessimistic attributional style $[6,10$, 13]. The process of learned helplessness deficits is outlined in figure 1.

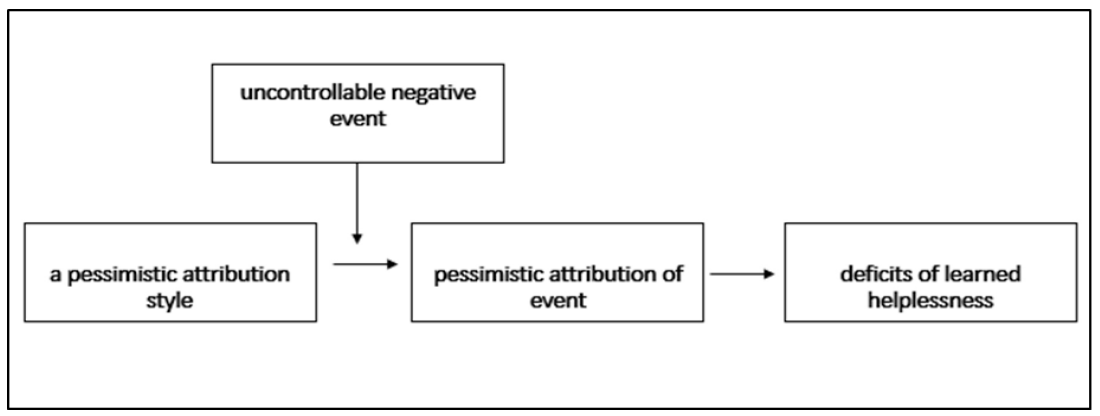

Figure 1. The process of learned helplessness deficits

The pessimistic attributional style is characterized by the explanation of adverse events and failures by internal and personal characteristics, and favorable events and successes - by external factors related to a particular sphere $[10$, p. 2]. The optimistic attributional style characterizes 
a person who tends to connect failures with coincidence happened at a certain point, and to perceive success situations as permanent, universal, caused by internal personal reasons $[10$, p. 2]. Thus, according to M. Seligman, the style of attribution allows filtering the experience of helplessness: in case of optimistic attributional style, the role of negative experience is downplayed, in case of pessimistic attributional style it is exaggerated [13].

It is important to note that not only the individuals with pessimistic attributional style can experience the state of learned helplessness. An uncontrollable negative event of high intensity or recurring uncontrollable negative events can cause deficits of learned helplessness of people with any style of attribution. This version of the learned helplessness origin is outlined in figure 2 .

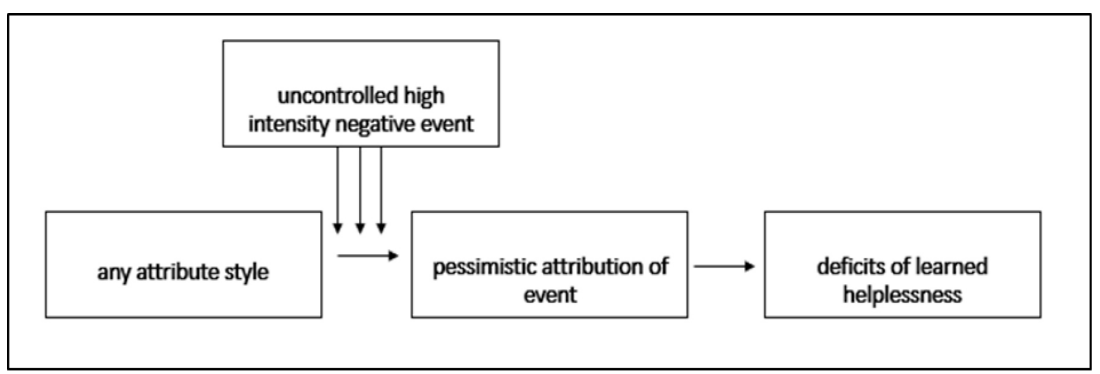

Figure 2. The version of emergence of learned helplessness

Thus, regardless of the peculiarities of explaining the reasons of what is happening, the individual may experience a state of learned helplessness facing an uncontrollable negative event of any intensity. In a state of learned helplessness, individuals experience a loss of control over their actions, believes that it is the environment but not they themselves manage life events. In case of moving to another country, the loss of self-control affects the individual's adaptation, focuses his/her attention on the current emotional state, actual negative emotions and feelings, but not on search for alternatives of actions and purposeful solution of adaptation to a new social and cultural environment issue. A new environment has an unpredictable and uncontrollable impact on migrants 
causing a state of learned helplessness thereby complicating the adaptation process and preventing successful integration into the host community. For more holistic and in-depth understanding of complexities in the system of migrants' adaptation, it is necessary to build a theoretical model to study learned helplessness as a personal state that complicates the processes of adaptation and integration of migrants into the host community. It seems appropriate to study the state of learned helplessness of migrants depending on the adaptation stage: preadaptation stage, adaptation stage during relocation, primary and secondary adaptation [7].

Preadaptation stage begins in the period of spring of migration motives in the country of residence of the individual. At this stage, the individual gathers information about peculiarities of living in the host country, sometimes goes there to get acquainted with the existing mode and tenor of life. This period also includes preparation of necessary documents, solving of formal issues, choosing of migration mechanism which collectively can affect further adaptation. I.B. Britvina notes that "the more carefully all the preparatory work is done at this stage, the less painful the adaptation will be" [1]. The emergence of a state of learned helplessness at this stage may be stipulated by a number of objective and subjective difficulties. Complexity of preparation of documents, the need to obey the formal rules, lack of information about a new place of residence, presentiment of the unknown and fear of events uncontrollability may cause learned helplessness and determine its deficits uprise. Cognitive and motivational deficits of learned helplessness at this stage of adaptation can be manifested in passivity in preparation for relocation, refusal of active actions and changes in external conditions, adaptation to them, can be characterized by difficulties in learning new ways of action. Having faced with external obstacles (temporary refusal of entry into the country, the need to correct the documents submitted, lack of support from relatives, etc.), an individual with learned helplessness lowers his/her hands, experiences anxiety, worries about the future, takes a dim view of the world. Overcoming the state of learned helplessness at this stage will prepare the subject for a new social and cultural environment, will lay the grounds for successful adaptation to a new place [9]. 
The next stage of migrants' adaptation to new conditions is adaptation during the relocation itself. At this stage, migrants become acquainted with the members of the host group, try to integrate with the new community, get new information about the country and gain some useful experience. This period is marked by the beginning of distress experience associated with acculturation, the severity of which depends on external circumstances and internal characteristics of the migrants. The state of learned helplessness at this stage can be caused by some language barrier, difficulties in establishing new connections, lack of close people around able to help and support. Ignoring the external manifestations of deficits of learned helplessness can lead to difficulties related to the implementation of the main purpose of relocation, as well as difficulties in adapting to new conditions and integration into the host community [1, p. 3].

The stage of primary adaptation can last from six months to two years. The deficiencies of learned helplessness can increase: pessimistic expectations, anxiety, refusal of active actions. Therefore, migrants have a strong need to communicate with members of the migrant community for assistance. Separate migrant settlements or communities appear at this stage, which hinders adaptation in a new cultural environment, but allows reducing the symptoms of learned helplessness. The negative effect of this adaptation can be the return to the country of origin. The stress of acculturation determines at this stage the highest manifestation of learned helplessness. The characteristics of the next stage of adaptation depend on the method of resolving the stress of acculturation and getting out of the state of learned helplessness [1, p. 3].

The stage of secondary adaptation can last up to 5-7 years [1]. The transition to this stage means success in acculturation, which makes it unlikely that the country will return to the country of outcome. At this stage of adaptation there are no manifestations of learned helplessness. Adapters have a system of social networks, not only within the migrant community, but also within the entire host group. They cease to perceive the cultural and ethnic characteristics of the host group tragically and with surprise. Stress acculturation ends integration with the new community. 


\section{Discussion}

A theoretical review of research on the problems of adaptation of migrants allows us to consider learned helplessness as a state accompanying adaptation in a new cultural environment. Learned helplessness, which arises as a reaction to uncontrolled events and cultural shock, greatly complicates favorable adaptation. Moreover, an increase in symptoms of learned helplessness at the stage of primary adaptation may lead to a return to the country of origin.

The findings are a theoretically valid hypothesis about the cultural and ethnic determinants of mental health of migrants. The findings are important for the socio-psychological support of change and integration of migrants, which is also the result of future research on how experience affects the values and more distant development processes of migrants in host communities.

Conflicts of Interest: The authors declare no conflict of interest. The funders had no role in the design of the study; in the collection, analyses, or interpretation of data; in the writing of the manuscript, and in the decision to publish the results.

Funding: The research was supported by the RFBR grant (project No. 19-013-00949 A Cultural and ethnic determinants of independence and personal helplessness of young people in Russia and CIS countries (as exemplified by the migrants from Central Asia)).

\section{References}

1. Britvina I.B. Osnovnye trudnosti i etapy adaptatsii vynuzhdennykh pereselentsev [The main difficulties and stages of adaptation of forced migrants]. Bulletin of KSU, Russia, 2006, №3, 53-56.

2. Dalgatov M.M., Davudova A.R. Lichnostnye kharakteristiki studentov s razlichnym atributivnym stilem [Personal values characteristics of the students with different attributive style]. Dagestan State Pedagogical University. Journal Psychological and Pedagogical Sciences, Russia, 2017, 11(4), 5-9. 
3. Gabdrakhmanova G.F., Sagdieva E.A., Korableva N.I. Studenty iz Tsentral'noy Azii v respublike Tatarstan: motivatsiya, adaptatsiya, zhiznennye plany [The students from central Asia in the republic of tatarstan: Motivation, adaptation, life plans]. Sociological studies, Russia, 2017, №3. 58-63.

4. Simanuk E.E. Psikhologicheskie determinanty razvitiya vyuchennoy bespomoshchnosti u uchiteley [Psychological determinants of the development of learned helplessness in teachers]. Bulletin of Tyumen State University, Russia, 2006, №1, 208-217.

5. Stefanenko T.G. Etnopsikhologiya [Ethnopsychology]. Moscow: Institute of Psychology under RAS, Academic Project, 1999. 320 p.

6. Tsiring D.A. Sovremennye podkhody k korrektsii vyuchennoy bespomoshchnosti u detey i podrostkov [Modern approaches to the correction of learned helplessness in children and adolescents]. Siberian psychological journal, Russia, 2008, №29, 63-68.

7. Volkova O.V. Stepen' razvitiya i istoriya problemy vyuchennoy bespomoshchnosti [Degree of development and history of the problem of learned helplessness]. Clinical and medical psychology: research, training, practice, Russia, 2013, 1(1).

8. Abramson L.Y., Seligman M.E.P., Teasdale J. Learned helplessness in humans: Critique and reformulation. Journal of Abnormal Psychology, 1978, 49-74. DOI: 10.1037/0021-843X.87.1.49.

9. Bosankic, N., Mešić, E., Sosic, B. The Floating Pumpkin Syndrome: Forced Migration, Humanitarian Aid, and the Culture of Learned Helplessness. Journal of Balkan and Near Eastern Studies. 2019, 21. 1-13. DOI:10.1080/19448953.2018.1532685.

10. Kwan S.O., Wong F.K. The relationship between attributional style and destructive responses to job dissatisfaction: an exploratory study of internal migrant workers in China. Health Psychol Behav Med. 2014, 2(1), 686-695. DOI:10.1080/21642850.2014.919864.

11. Palmer D., Ward K., Lost: listening to the voices and mental health needs of forced migrants in London, Medicine, Conflict and Survival, 2007, 23:3, 198-212, DOI: 10.1080/13623690701417345.

12. Sandell, E.J., \& Tupy, S.J. (2015). Where Cultural Competency Begins: Changes in Undergraduate Students' Intercultural Competency. Inter- 
national Journal of Teaching and Learning in Higher Education, 27(3), 364-381.

13. Seligman M.E.P. Helplessness: On depression, development, and death. San Francisco: Freeman, 1975.

14. Sosic B. Mental health in forced migration: development and adaptation. 2018, DOI: 10.13140/RG.2.2.19993.88162.

15. Warikoo N., \& Carter P. (2009). Cultural Explanations for Racial and Ethnic Stratification in Academic Achievement: A Call for a New and Improved Theory. Review of Educational Research, 79(1), 366-394.

\section{Список литературы}

1. Брытвина И.Б. Основные трудности и этапы адаптации вынужденных переселенцев // Вестник КГУ, 2006. №3. С. 53-56.

2. Далгатов М.М., Давудова А.Р. Личностные характеристики студентов с различным атрибутивным стилем // Журнал психолого-педагогических наук. Дагестанский государственный педагогический университет, 2017. №11 (4). С. 5-9.

3. Габдрахманова Г.Ф., Сагдиева Е.А., Кораблева Н.И. Студенты из Центральной Азии в республике Татарстан: мотивация, адаптация, жизненные планы // Социологические исследования, 2017. №3. С. 58-63.

4. Симанюк Е. Е. Психологические детерминанты развития выученной беспомощности у учителей // Вестник Тюменского государственного университета, 2006. №1. С. 208-217.

5. Стефаненко Т.Г. Этнопсихология. М.: Институт психологии РАН, 1999. $320 \mathrm{c}$.

6. Циринг Д.А. Современные подходы к коррекции выученной беспомощности у детей и подростков // Сибирский психологический журнал, 2008. № 29. С. 63-68.

7. Волкова О.В. Степень развития и история проблемы выученной беспомощности // Клиническая и медицинская психология: исследования, обучение, практика, 2013. № 1 (1).

8. Abramson L.Y., Seligman M.E.P., Teasdale J. Learned helplessness in humans: Critique and reformulation. Journal of Abnormal Psychology, 1978, 49-74. DOI: 10.1037/0021-843X.87.1.49. 
9. Bosankic N., Mešić E., Sosic B. The Floating Pumpkin Syndrome: Forced Migration, Humanitarian Aid, and the Culture of Learned Helplessness. Journal of Balkan and Near Eastern Studies. 2019, 21. 1-13. DOI:10.10 80/19448953.2018.1532685.

10. Kwan S.O., Wong F.K. The relationship between attributional style and destructive responses to job dissatisfaction: an exploratory study of internal migrant workers in China. Health Psychol Behav Med. 2014, 2(1), 686-695. DOI:10.1080/21642850.2014.919864.

11. Palmer D., Ward K., Lost: listening to the voices and mental health needs of forced migrants in London, Medicine, Conflict and Survival, 2007, 23:3, 198-212, DOI: 10.1080/13623690701417345.

12. Sandell, E.J., \& Tupy, S.J. (2015). Where Cultural Competency Begins: Changes in Undergraduate Students' Intercultural Competency. International Journal of Teaching and Learning in Higher Education, 27(3), 364-381.

13. Seligman M.E.P. Helplessness: On depression, development, and death. San Francisco: Freeman, 1975.

14. Sosic B. Mental health in forced migration: development and adaptation. 2018, DOI: 10.13140/RG.2.2.19993.88162.

15.Warikoo N., \& Carter P. (2009). Cultural Explanations for Racial and Ethnic Stratification in Academic Achievement: A Call for a New and Improved Theory. Review of Educational Research, 79(1), 366-394.

\section{DATA ABOUT THE AUTHORS}

Ponomareva Irina Vladimirovna, Head of the Department of Psychology, Ph.D. in Psychology

Chelyabinsk State University

129, Kashirin brothers St., Chelyabinsk, 454001, Russian Federation

Ivp-csu@yandex.ru

SPIN-code: 8645-9023

ORCID: 0000-0001-8600-3533

ResearcherID: E-8773-2017 
Sizova Yana Nikolaevna, Senior Lecturer of Psychology

Chelyabinsk State University

129, Kashirin brothers St., Chelyabinsk, 454001, Russian Federation

Sizova159@yandex.ru

SPIN-code: 2960-1491

ORCID: 0000-0001-9000-7238

ResearcherID: B-4702-2018

\section{ДАННЫЕ ОБ АВТОРАХ}

Пономарева Ирина Владимировна, заведующий кафедрой психологии, кандидат психологических наук, доцент Челябинский государственный университет ул. Братьев Кашириных, 129, г. Челябинск, 454001, Российская Федераичи Ivp-csu@yandex.ru

Сизова Яна Николаевна, старший преподаватель кафедры психологии

Челябинский государственный университет

ул. Братьев Кашириных, 129, г. Челябинск, 454001, Российская Федераичи

Sizova159@yandex.ru

SPIN-code: 2960-1491

ORCID: 0000-0001-9000-7238

ResearcherID: B-4702-2018 